\title{
Optimization of Abrasive Water Jet Machining Parameters for $\alpha-\beta$ brass using Taguchi Methodology
}

Department of Mechanical Engineering CMR Institute of Technology, Hyderabad

India

\section{Ravichandran}

Associate Professor Department of Mechanical Engineering K.Ramakrishnan College of Engineering Tiruchirappall India

\section{B. Stalin}

Department of Mechanical Engineering Anna University, Regional Campus Madurai India

\section{B. Sridhar Babu}

Professor

Department of Mechanical Engineering CMR Institute of Technology, Hyderabad
The usages of nonferrous alloys in industries are rapidly increasing due to their excellent properties such as strength, ductility, malleability, toughness and corrosion resistance. Brass is one of the nonferrous alloy which is used in many applications such as automobile, aerospace medical and electrical fields. In this experimental investigation, $\alpha-\beta$ brass was formulated by stir casting technique and the material characterization is examined with the Scanning Electron Microscope and Energy Dispersive Analysis of X-rays. The process parameters of Abrasive Water Jet Machining such as water pressure, traverse speed and mass flow rate are considered to study the machining of $\alpha-\beta$ brass using the Taguchi methodology. The effect of these process parameters on the responses such as Surface Roughness and Material Removal Rate were studied by varying the control process parameters. The optimum permutation of the process parameters were identified for maximum MRR and minimum SR. The most prominent parameters were found out by Analysis of Variance.

Keywords: Abrasive Water Jet Machining, $\alpha-\beta$ Brass, Material Removal Rate, Surface Roughness, Taguchi methodology, Analysis of Variance..

\section{INTRODUCTION}

Abrasive water jet machining (AWJM) is one of the economical unconventional machining processes and it gives better accuracy and surface finish. The main advantages of AWJM process are the higher amount of material removed, high flexibility, least amount of cutting force and thermal stresses are developed during machining of materials [1]. Surface quality variations and machining behaviors were analyzed during the water jet machining process [2]. AWJM is one of the cost effective methods and it is used to cut hard mate-rials. Brass and its alloys play a vital role in industries due to its excellent properties such as strength, hardness, higher plasticity and corrosion resistance [3,4]. The experiment was designed by the Taguchi technique which offers a simple, capable and systematic advance to conclude optimal contribution parameters [5]. Minimization and maximization quality characteristics were depending upon the signal to noise ratio $[6,7]$. The phase behavior and grain refinement were studied in $\mathrm{Cu}-\mathrm{Zn}$ alloy [8]. The process parameters, namely traverse speed, abrasive mass flow rate, standoff distance and water pressure and its effect on surface quality were studied [9-11]. Taguchi technique and analysis of variance (ANOVA) were used during abrasive water jet machining of graphite/epoxy laminates, and it conc-luded that standoff distance has the most significant influence on surface roughness [12]. By using Taguchi method the optimized cutting parameters were

Received: June 2018, Accepted: September 2018

Correspondence to: Dr. B.Stalin

Assistant Professor, Faculty of Mechanical Engineering, Anna University, Regional Campus Madurai, India

E-mail: stalin1312@gmail.com

doi: 10.5937/fmet1901116M

(C) Faculty of Mechanical Engineering, Belgrade. All rights reserved found in hard turning of steels with ceramic tools [13]. In Taguchi method, for three control parameters $\mathrm{L}_{9}$ orthogonal array was considered [14]. Taguchi based parametric optimization was carried out using abrasive water jet machining of different materials such as Stainless Steel [15], 6063-T6 aluminum alloy [16] Mild Steel [17], polyester hybrid composite [18], Inconel 718 [19], Inconel $800 \mathrm{H}[20]$.

In this paper, stir casting technique is used for fabricated work material such as $\alpha-\beta$ brass and the material characterization is investigated with the Scanning Electron Microscope (SEM) and Energy Dispersive Analysis of X-rays (EDAX). The stir casted $\alpha-\beta$ brass is machined by abrasive water jet machining process. The material removal rate and surface roughness are considered as the important performance measures in various industrial applications. Parametric optimization and the effects of water pressure, traverse speed, abrasive flow rate on material removal rate and surface roughness are analyzed by Taguchi method.

\section{MATERIALS FABRICATION AND CHARACTERIZATION}

The work material $\alpha-\beta$ brass was fabricated through stir casting technique. The billet of copper and zinc is placed into the graphite crucible and it was preheated at $480^{\circ} \mathrm{C}$ for 45 minutes before melting to formulate their surfaces oxidized. By diffusing 40 weight percentage of zinc in 60 weight percentage of copper melted at 1200 ${ }^{\circ} \mathrm{C}$. The muddle is stirred continuously. The uniform mixing was ensured by stirring system with $700 \mathrm{rpm}$ speed. The slurry was poured in a cast iron mould to obtain standard specimens of size $100 \times 50$ x $10 \mathrm{~mm}$. The composition and content was ensured by Energy Dispersive Analysis of X-rays which is shown in Fig.1. 


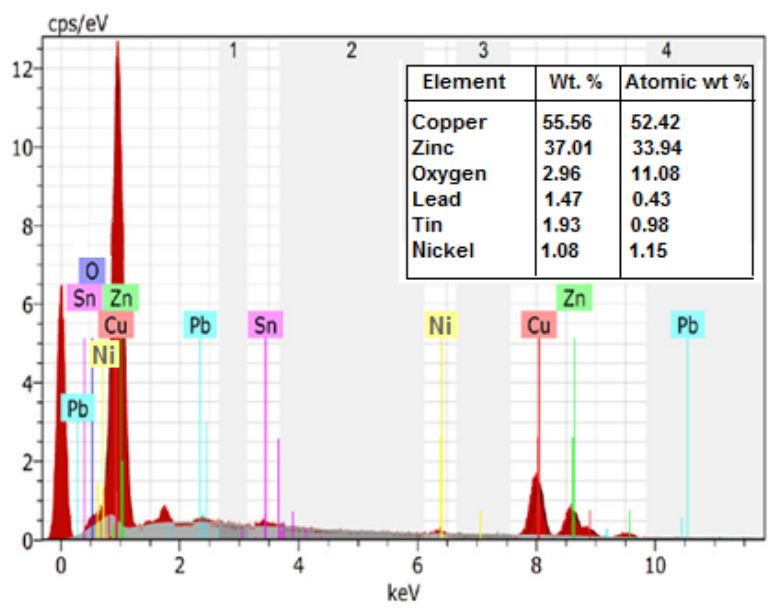

Figure 1. EDAX image of $\alpha-\beta$ brass

From Fig. 1, Copper and Zinc elements are the major compositions of $\alpha-\beta$ brass. Lead, tin and nickel elements are minor compositions of $\alpha-\beta$ brass.

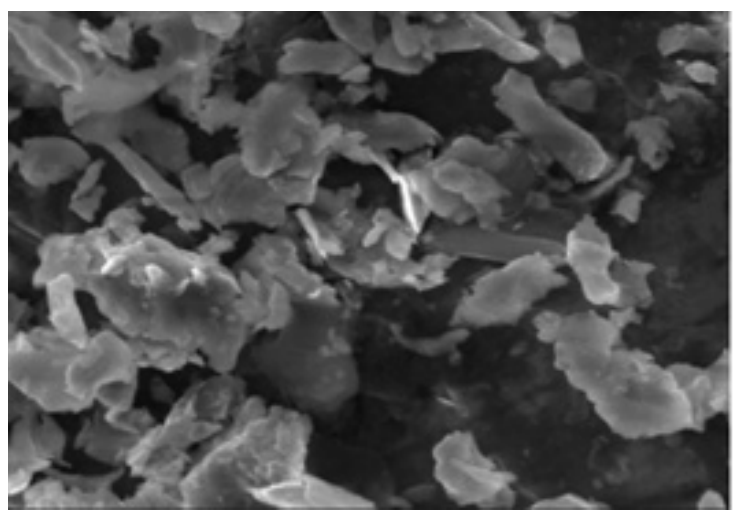

Figure 2. SEM image of $\alpha-\beta$ brass

The morphology of the $\alpha-\beta$ brass was studied with the SEM shown in Fig. 2. From the image it is obvious that $\alpha$ and $\beta$ phases are produced by stir casting method. It is examined that the zinc was dissolved in the copper during stir casting process. The distribution of zinc in the copper is consistent and it was attained by the uniform of stirring process.

\section{EXPERIMENTAL DETAILS}

Parameters were selected based on the literature review. These three parameters only have provided maximum contribution effect while machining of $\alpha-\beta$ brass The levels of parameters are represented in Table 1 .

The machining (drill $6 \mathrm{~mm}$ diameter holes) operation was performed by using AWJM. Three input parameters were selected, namely water pressure, traverse speed and mass flow rate.

Table 1. Level of control parameters

\begin{tabular}{|c|c|c|c|}
\hline Levels & $\begin{array}{c}\text { Water } \\
\text { Pressure } \\
\text { (bar) }\end{array}$ & $\begin{array}{c}\text { Traverse } \\
\text { Speed } \\
(\mathrm{mm} / \mathrm{min})\end{array}$ & $\begin{array}{c}\text { Abrasive } \\
\text { Flow rate } \\
(\mathrm{gm} / \mathrm{mm})\end{array}$ \\
\hline 1 & 2000 & 35 & 100 \\
\hline 2 & 2500 & 70 & 150 \\
\hline 3 & 3000 & 100 & 200 \\
\hline
\end{tabular}

The response parameters such as Material Removal Rate (MRR) and Surface Roughness (SR) were mea- sured. The surface roughness is measured by Mitutoyo Talysurf-SJ-201 surface tester. The properties of $\alpha-\beta$ brass is evaluated and listed in the Table 2.

Table 2. Material properties of the $\alpha-\beta$ brass

\begin{tabular}{|c|c|c|}
\hline S.No. & Properties & Results \\
\hline 1 & Hardness (BHN) & $120 \mathrm{BHN}$ \\
\hline 2 & Tensile strength (MPa) & $510 \mathrm{Mpa}$ \\
\hline 3 & Impact strength $(\mathrm{J})$ & $11 \mathrm{~J}$ \\
\hline 4 & Percentage of elongation & 12 \\
\hline 5 & Density (g/cc) & 8.32 \\
\hline
\end{tabular}

Brinell hardness testing machine, Universal testing machine and Charpy testing machine are used to find the material properties. Archimedes principle is used to find the density of the material.

\section{RESULTS AND DISCUSSION}

The responses such as MRR and SR of the holes were evaluated by varying the control parameters. These two responses are very important for machining of any materials [21]. The drilling operation was completed according to $\mathrm{L}_{9}$ orthogonal array [22]. Table 3 shows the abrasive water jet machining experimental layout and its results.

Table 3. The abrasive water jet machining experimental results

\begin{tabular}{|c|c|c|c|c|c|}
\hline S.No. & $\begin{array}{c}\text { A:Water } \\
\text { Pressure } \\
(\text { bar })\end{array}$ & $\begin{array}{c}\text { B:Traverse } \\
\text { Speed } \\
(\mathrm{mm} / \mathrm{min})\end{array}$ & $\begin{array}{c}\text { C:Abrasive } \\
\text { Flow rate } \\
(\mathrm{gm} / \mathrm{mm})\end{array}$ & $\begin{array}{c}\text { SR } \\
(\mu \mathrm{m})\end{array}$ & $\begin{array}{c}\text { MRR } \\
(\mathrm{gm} / \mathrm{min})\end{array}$ \\
\hline 1 & 2000 & 35 & 100 & 1.99 & 6.61 \\
\hline 2 & 2000 & 70 & 150 & 2.01 & 7.43 \\
\hline 3 & 2000 & 100 & 200 & 2.11 & 10.23 \\
\hline 4 & 2500 & 35 & 150 & 3.32 & 13.65 \\
\hline 5 & 2500 & 70 & 200 & 2.13 & 12.34 \\
\hline 6 & 2500 & 100 & 100 & 3.56 & 10.43 \\
\hline 7 & 3000 & 35 & 200 & 4.33 & 14.75 \\
\hline 8 & 3000 & 70 & 100 & 1.45 & 11.25 \\
\hline 9 & 3000 & 100 & 150 & 1.67 & 17.31 \\
\hline
\end{tabular}

The loss of mass is measured before and after each machining operation which provides net MRR.

\subsection{Taguchi parametric optimization}

The $\mathrm{L}_{9}$ orthogonal array is used to offer the improved features, and decrease the number of experimentations. In this experiment, three control parameters were used with three levels, namely low, medium and high. Taguchi technique is extensively used to attain the quality optimization in many industries. The assessment of quality characteristics is completed through $\mathrm{S} / \mathrm{N}$ ratio.

\section{$3.2 \mathrm{~S} / \mathrm{N}$ ratio analysis for MRR}

The signal to noise ratio ( $\mathrm{S} / \mathrm{N}$ ratio) is the most significant factor to forecast the optimal outcome. The essential output characteristics were considered by $\mathrm{S} / \mathrm{N}$ ratio whether it must be minimum or maximum as per their experimentation [6].

In this experimentation, maximum MRR and minimum SR of the holes were considered. Hence, larger the 
better criteria is selected for MRR and smaller the better criteria is selected for surface roughness of the holes. Mean of $\mathrm{S} / \mathrm{N}$ ratio for MRR is listed in the Table 4.

Table 4. Mean of $\mathrm{S} / \mathrm{N}$ ratio for MRR

\begin{tabular}{|c|c|c|c|}
\hline Level & $\begin{array}{c}\text { Water } \\
\text { pressure } \\
\text { (bar) }\end{array}$ & $\begin{array}{c}\text { Traverse } \\
\text { Speed } \\
(\mathrm{mm} / \mathrm{min})\end{array}$ & $\begin{array}{c}\text { Abrasive } \\
\text { flow rate } \\
(\mathrm{gm} / \mathrm{mm})\end{array}$ \\
\hline 1 & 8.090 & 11.670 & 9.430 \\
\hline 2 & 12.140 & 10.340 & 12.797 \\
\hline 3 & 14.437 & 12.657 & 12.440 \\
\hline Delta & 6.347 & 2.317 & 3.367 \\
\hline Rank & 1 & 3 & 2 \\
\hline
\end{tabular}

Figure 3 shows that the main effects plot for various levels of the parameters for MRR. To attain highest MRR, larger the better criterion was chosen. Hence the optimal level of parameter $A_{3} B_{3} C_{3}$ was selected from the $\mathrm{S} / \mathrm{N}$ ratio graph as shown in Fig.3.

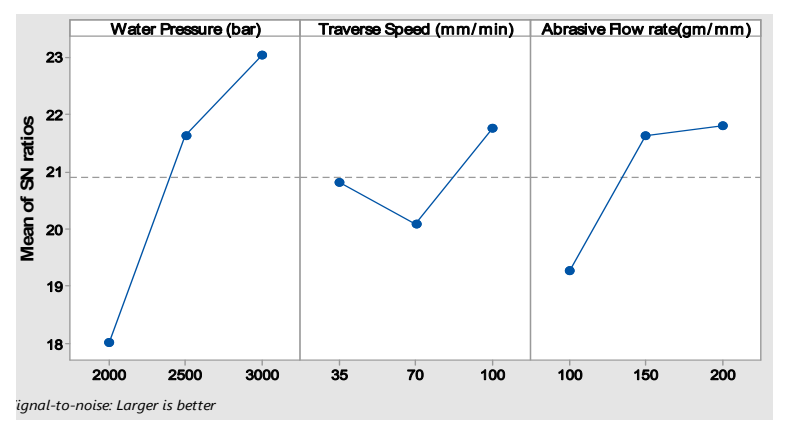

Figure 3. Signal to Noise ratio graph for MRR

The optimal combination values for material removal rate are water pressure of 3000 bar, Traverse speed of $100 \mathrm{~mm} / \mathrm{min}$ and abrasive flow rate of $200 \mathrm{gm} / \mathrm{mm}$.

In the present study ANOVA is used to find out the influence of contribution process parameters such water pressure, traverse speed and mass flow rate on the responses such as material removal rate and surface roughness during machining of $\alpha-\beta$ brass which was produced through stir casting technique.

Table 5. ANOVA table for the MRR

\begin{tabular}{|c|c|c|c|c|c|}
\hline Source & DF & $\begin{array}{c}\text { Adj } \\
\text { SS }\end{array}$ & $\begin{array}{c}\text { Adj } \\
\text { MS }\end{array}$ & $\begin{array}{c}\text { F- } \\
\text { Value }\end{array}$ & $\begin{array}{c}\text { P- } \\
\text { Value }\end{array}$ \\
\hline $\begin{array}{c}\text { Water } \\
\text { pressure }\end{array}$ & 2 & 61.96 & 30.98 & 26.62 & 0.036 \\
\hline $\begin{array}{c}\text { Traverse } \\
\text { speed }\end{array}$ & 2 & 8.11 & 4.06 & 3.48 & 0.22 \\
\hline $\begin{array}{c}\text { Abrasive } \\
\text { flow rate }\end{array}$ & 2 & 20.52 & 10.26 & 8.82 & 0.10 \\
\hline Error & 2 & 2.328 & 1.164 & & \\
\hline Total & 8 & 92.91 & & & \\
\hline \multicolumn{2}{|c|}{} \\
\hline
\end{tabular}

Table 5 shows the results of ANOVA for MRR. It is consummated that, the water pressure is the leading contributing factor of influence on the material removal rate.

Figure 4 shows that interaction of water pressure, traverse speed and mass flow rate for the response material removal rate. It is observed that, water pressure is most contributory factor which affects the material removal rate.

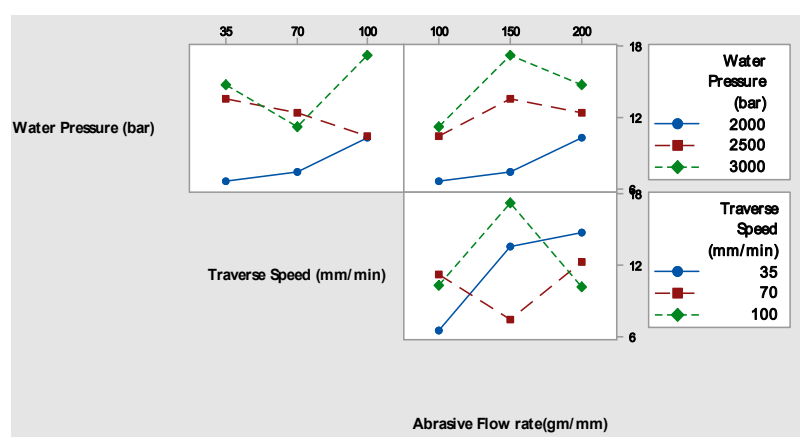

Figure 4. Interaction of water pressure, traverse speed and mass flow rate with MRR

\section{3 $\mathrm{S} / \mathrm{N}$ ratio analysis for surface roughness}

Since require minimum surface roughness of the holes, smaller the better characteristic is considered. Signal to noise ratio was computed for minimization quality characteristics of output response such as surface roughness. Response values for $\mathrm{S} / \mathrm{N}$ ratio are given in Table 6 .

Table 6. Response values for $\mathrm{S} / \mathrm{N}$ ratio of surface roughness

\begin{tabular}{|c|c|c|c|}
\hline Level & $\begin{array}{c}\text { Water } \\
\text { pressure(bar) }\end{array}$ & $\begin{array}{c}\text { Traverse } \\
\text { Speed } \\
(\mathrm{mm} / \mathrm{min})\end{array}$ & $\begin{array}{c}\text { Abrasive } \\
\text { flow rate } \\
(\mathrm{gm} / \mathrm{mm})\end{array}$ \\
\hline 1 & -18.01 & -20.83 & -19.26 \\
\hline 2 & -21.63 & -20.09 & -21.63 \\
\hline 3 & -23.05 & -21.78 & -21.80 \\
\hline Delta & 5.05 & 1.69 & 2.54 \\
\hline Rank & 1 & 3 & 2 \\
\hline
\end{tabular}

To accomplished minimum surface roughness of the holes, smaller the better condition was chosen. Hence the optimal level of parameter A3 B3 C3 was selected from the graph as shown in Fig. 5.

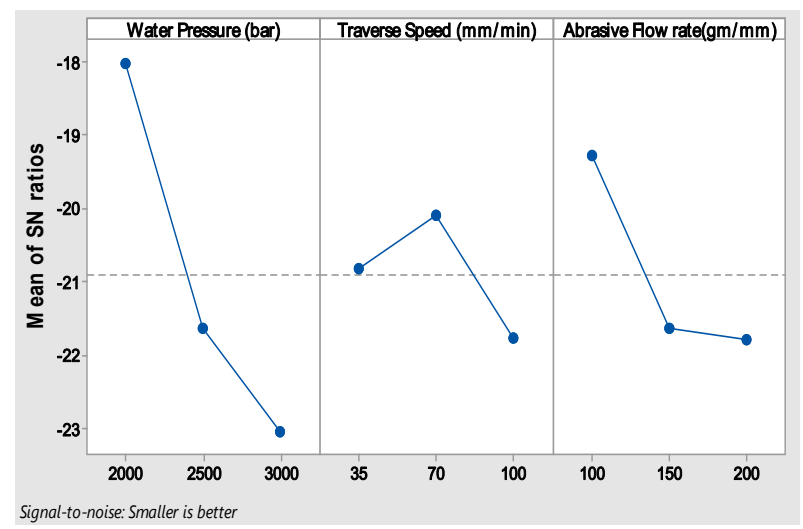

Figure 5. S/N ratio graph for surface roughness of the holes

The optimal values for circularity of the holes are water pressure of $3000 \mathrm{bar}$, Traverse speed of $100 \mathrm{~mm}$ $/ \mathrm{min}$ and abrasive flow rate of $200 \mathrm{gm} / \mathrm{mm}$. Table 7 shows the results of ANOVA for surface roughness of the holes. It is consummated that, the water pressure is the leading factor for influence on the response such as surface roughness with R-squared values greater than 90 .

Figure 6 shows the interaction of traverse speed, mass flow rate and water pressure for the response as surface roughness of the holes. It is perceived that the most governing factor is water pressure among all control factors, and water pressure has a more interaction 
effect on surface roughness of the holes. A mathematical model was generated for abrasive water jet machining of $\alpha-\beta$ brass and it is used to forecast the responses such as material removal rate and surface roughness.

Table 7. ANOVA for surface roughness of the holes

\begin{tabular}{|c|c|c|c|c|c|}
\hline Source & DF & Adj SS & Adj MS & F-Value & P-Value \\
\hline $\begin{array}{c}\text { Water } \\
\text { pressure }\end{array}$ & 2 & 3.5747 & 1.7873 & 0.72 & 0.583 \\
\hline $\begin{array}{c}\text { Traverse } \\
\text { speed }\end{array}$ & 2 & 1.6028 & 0.8014 & 0.32 & 0.757 \\
\hline $\begin{array}{c}\text { Abrasive } \\
\text { flow rate }\end{array}$ & 2 & 0.9074 & 0.4537 & 0.18 & 0.846 \\
\hline Error & 2 & 4.9930 & 2.4965 & & \\
\hline \multicolumn{7}{|c|}{ Total } & 8 & 11.0778 & & & \\
\hline \multicolumn{6}{|c|}{$\mathrm{S}=1.581 ;$ R-sq $=96.25 \% ;$ R-sq (adj) $=89.19 \%$}
\end{tabular}

$$
\begin{aligned}
\operatorname{MRR}\left(\frac{g m}{\min }\right)= & 11.556-3.446 A-2000+0.584 A-250+2.881 A- \\
& -3000+0.114 B-35-1.216 B-70+1.101 B-100- \\
& -2.126 C-100+1.241 C-150+0.884 C-200 \\
S R(\mu m)= & 2.648-0.888 A-2000+0.512 A-2500+0.32 A \\
- & 3000+0.436 B-35-0.571 B-70+0.136 B-100 \\
- & 0.434 C-150+0.316 C-200
\end{aligned}
$$

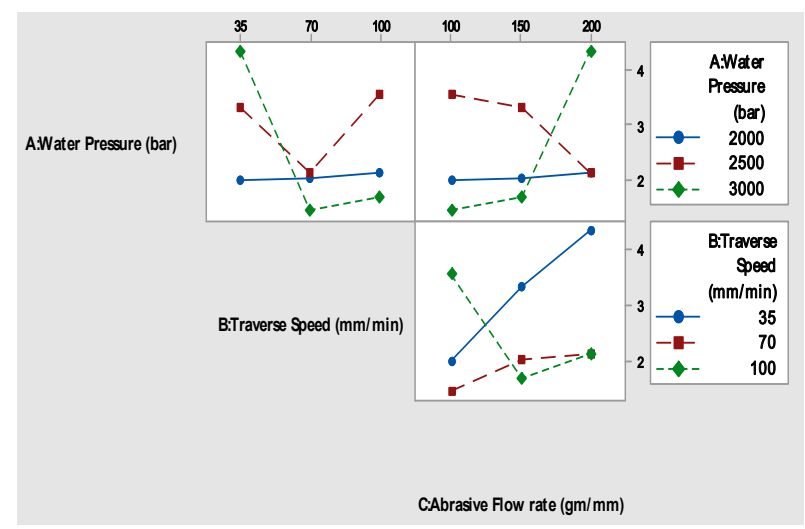

Figure 6. Interaction of water pressure, traverse speed and mass flow rate with $S R$

\section{CONTOUR PLOT ANALYSIS}

Figure 7 shows the contour plots for MRR. Figure 7(a) shows the higher MRR has been achieved when the range of water pressure is 2800 - 3000 bar and abrasive flow rate is $140-180 \mathrm{gm} / \mathrm{min}$. Figure $7(\mathrm{~b})$ shows the higher MRR has been achieved when the abrasive flow rate is $160-200 \mathrm{gm} / \mathrm{min}$. Figure 7 (c) shows the higher MRR has been achieved when the traverse speed is $100 \mathrm{~mm} / \mathrm{min}$ and water pressure is 3000 bar. The higher amount of material removal rate is attained by increase the water pressure.

Figure 8 shows the contour plots for surface roughness of the holes. Figure 8(a) shows the minimum surface roughness of the holes has been obtained when the range of the water pressure is 2000-2200 bar. Figure 8 (b) shows the minimum surface roughness of the holes has been achieved when the range of abrasive flow rate is $100-200 \mathrm{gm} / \mathrm{min}$. Figure $8(\mathrm{c})$ shows that the minimum surface roughness of the holes can be achieved with the gradual difference between traverse speed and abrasive flow rate.

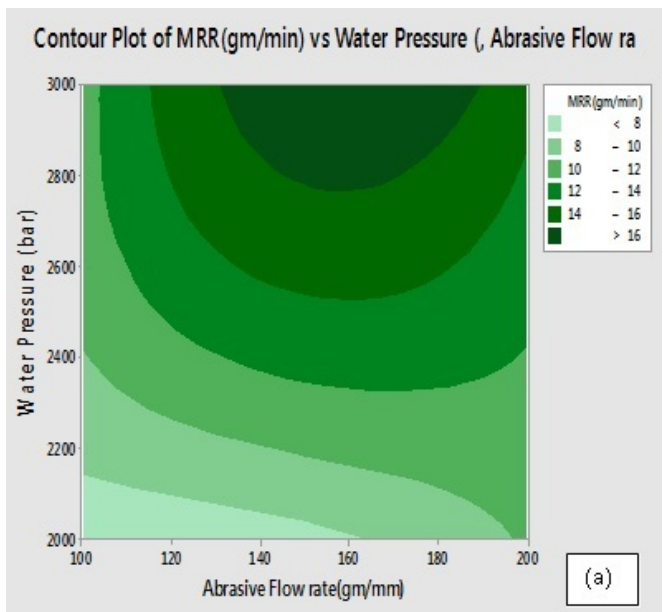

Contour Plot of MRR(gm/min) vs Traverse Speed ( Abrasive Flow ra

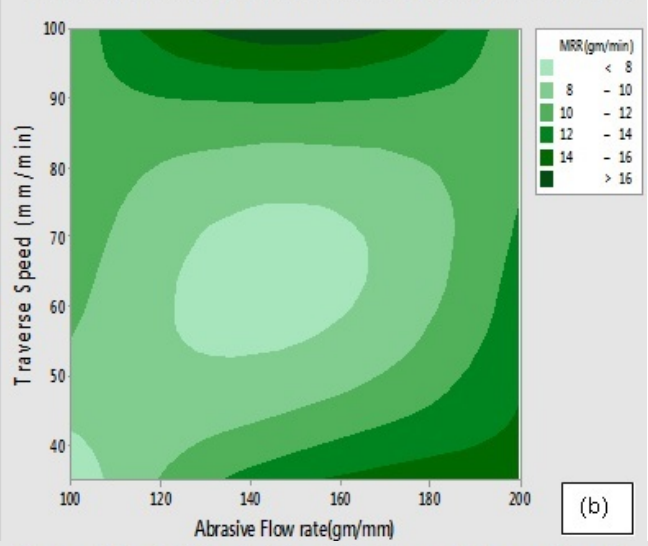

Contour Plot of MRR(gm/min) vs Water Pressure (, Traverse Speed (

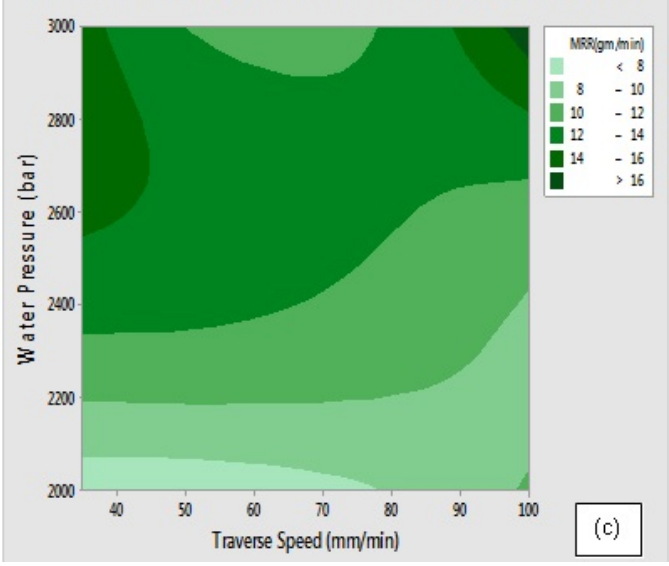

Figure 7(a-c). Contour plots for MRR (gm/min) (a) water pressure vs abrasive flow rate (b) traverse speed vs abrasive flow rate (c) water pressure vs traverse speed

Contour Plot of SR( $\mu \mathrm{m})$ vs Water Pressure (, Traverse Speed (

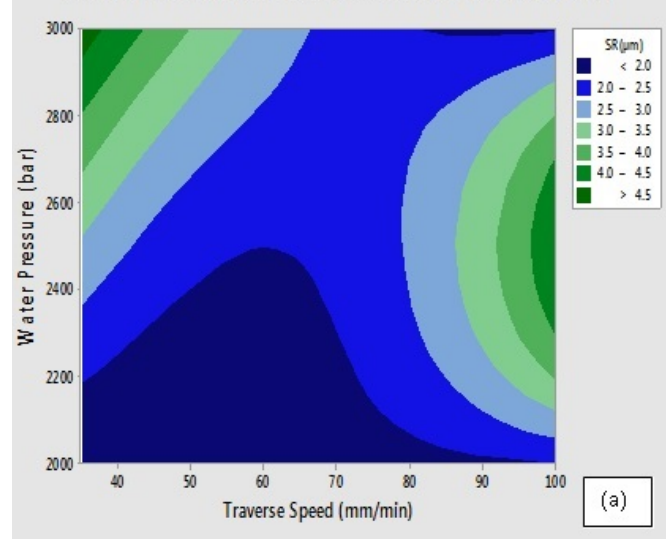




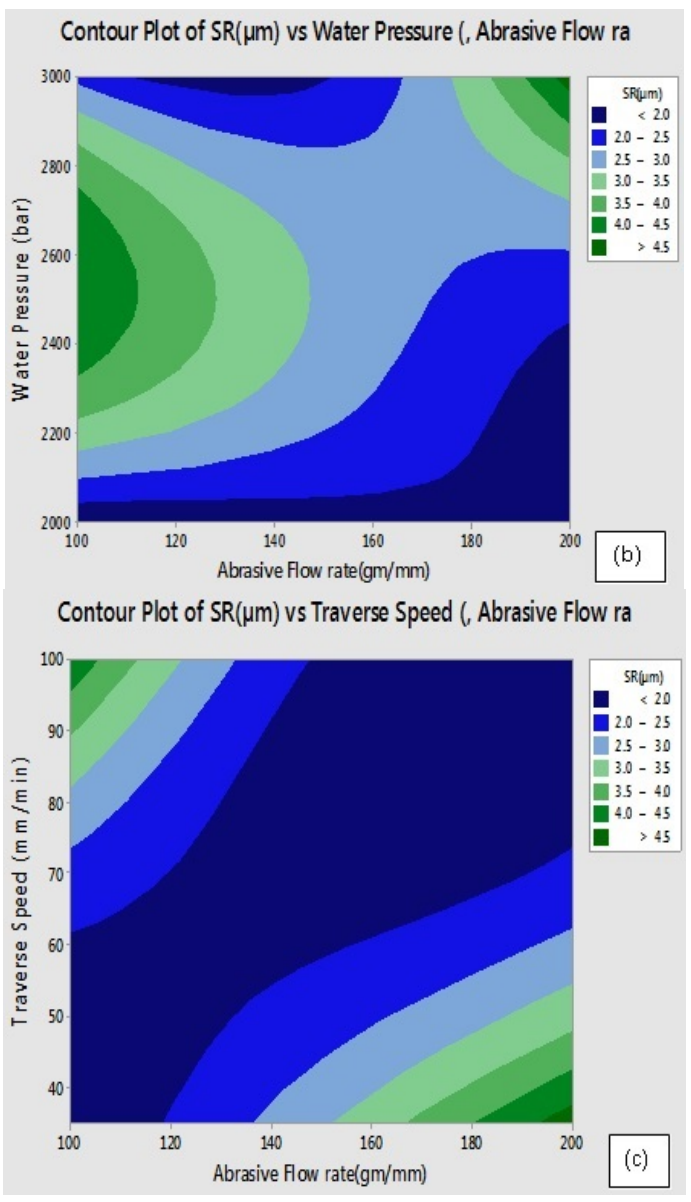

Figure 8(a-c). Contour plots for Surface Roughness $(\mu \mathrm{m})$ of the holes (a) water pressure vs traverse speed (b) water pressure vs abrasive flow rate (c) traverse speed vs abrasive flow rate

\section{CONCLUSIONS}

After successful completion of all experimental analyses, the following conclusions were drafted

- The work material $\alpha-\beta$ brass was successfully fabricated by stir casting technique.

- The morphology of the $\alpha-\beta$ brass was deliberated through SEM and composition was confirmed through EDAX.

- The stir casted $\alpha-\beta$ brass was successfully machined by AWJM process.

- The Taguchi methodology applied was it feasible. The optimal solutions were found out and proven by Taguchi method and its listed below;

(i) Water pressure $=3000 \mathrm{bar}$,

(ii) Traverse speed $=100 \mathrm{~mm} / \mathrm{min}$,

(iii) Abrasive flow rate $=200 \mathrm{gm} / \mathrm{mm}$.

- From analysis of variance, the water pressure is the foremost factor to affect the responses such as MRR and surface roughness of the holes.

- The interaction between control parameters and response parameters were studied through contour plot analysis.

- The results proved that the Taguchi analysis is accurate and the developed mathematical model will be used in any industrial environment.

\section{REFERENCES}

[1] Momber, A., Kovaĉević, R.: Principles of Abrasive Water Jet Machining, Springer-Verlag, London, 1998.

[2] Cojbasic, Z., Petkovic, D., Shamshirband, S., Wen Tong, C., Sudheer Ch, Jankovic, P., Ducic, N. and Baralic, J.: Surface roughness prediction by extreme learning machine constructed with abrasive water jet, Precision Engineering, Vol. 43, pp. 86 92, 2016.

[3] Li, S., Imai, H., Atsumi, H. and Kondoh, K.: Contribution of $\mathrm{Ti}$ addition to characteristics of extruded $\mathrm{Cu} 40 \mathrm{Zn}$ brass alloy prepared by powder metallurgy, Mater. Des., Vol. 32, No. 1, pp. 192197, 2011.

[4] Amirat, M., Zaïdi, H., Djamaï, A., Necib, D. and Eyidi, D.: Influence of the gas environment on the transferred film of the brass (Cu64Zn36)/steel AISI 1045 couple, Wear, Vol. 267, pp. 433-440, 2009.

[5] George, P.M., Raghunath, B.K., Manocha, L.M. and Warrier, A.M.: EDM machining of carboncarbon composite - a Taguchi approach, J. Mater. Process. Technol., Vol. 145, No.1, pp. 66-71, 2004.

[6] Che-Chung Wang, Han-Ming Chow, Lieh-Dai Yang and Chun-Te Lu: Recast layer removal after electrical discharge machining via Taguchi analysis: A feasibility study, J. Mater. Process. Technol., Vol. 209, No. 8, pp. 4134-4140, 2009.

[7] Ugrasen, G., Ravindra, H.V., Naveen Prakash, G.V. and Theertha Prasad, Y.N.: Optimization of process parameters in wire EDM of $\mathrm{HCHCr}$ material using Taguchi's technique, Mater. Today: Proc., Vol. 2, No.4-5, pp. 2443-2452, 2015.

[8] Peng, K., Su, L., Shawb, L.L and Qian, K.W.: Grain refinement and crack prevention in constrained groove pressing of two-phase $\mathrm{Cu}-\mathrm{Zn}$ alloys, Sci. Mater., Vol. 56, pp. 987-990, 2007.

[9] Kovacevic, R.: Surface texture in abrasive waterjet cutting, J. Manuf. Syst., Vol. 10, pp. 32 -40, 1991.

[10]Akkurt, A., Kulekci, M.K., Seker, U. and Ercan, F.: Effect of feed rate on surface roughness in abrasive waterjet cutting applications, J. Mater. Process. Technol., Vol. 147, pp. 389 -396, 2004.

[11] Axinte, D.A., Srinivasu, D.S., Kong, M.C. and Butler-Smith, P.W.: Abrasive waterjet cutting of polycrystalline diamond; A preliminary investigation, Int. J. Mach. Tools Manuf., Vol. 49, pp. 797-803, 2008.

[12] Ramulu, M. and Arola, D.: The influence of abrasive water jet cutting conditions on the surface quality of graphite/epoxy laminates, Int. J. Mach. Tools Manuf., Vol. 34, No. 3, pp. 295-313, 1994.

[13] Ersan Aslan, Camuscu, N., Birgoren, B.: Design optimization of cutting parameters when turning hardened AISI 4140 steel (63 HRC) with $\mathrm{Al}_{2} \mathrm{O}_{3}+\mathrm{TiCN}$ mixed ceramic tool, Mater. Des., Vol. 28, No. 5, pp. 1618-1622, 2007.

[14] Ramprasad, Upadhyay, G., Hassan, K.: Optimization MRR of stainless steel 403 in abrasive water 
jet machining using Anova and Taguchi method," Int. J. Eng. Res. Appl., Vol. 5, No. 5, pp. 86-91, 2015.

[15] Jurkovic, Z., Perinic, M., Maricic, S., Sekulic, M. and Mandic, V.: Application of modelling and optimization methods inabrasive water jet machining, J. Trends Dev. Mach. Assoc. Technol., Vol. 16, No. 1, pp. 59-62, 2012.

[16] Kolahan, F. and Khajavi, H.: Modeling and optimization of abrasive waterjet parameters using regression analysis, World Acad. Sci. Eng. Technol., Vol. 59, pp. 488-493, 2009.

[17] Thakkar, P.K.H., Prajapati, P.V.M. and Thakkar, P.S.: A Machinability Study of Mild Steel using Abrasive Water Jet Machining Technology, Int. J. Eng. Res. Appl., Vol. 3, No. 3, pp. 1063-1066, 2013.

[18] Arumuga Prabu, V., Thirumalai Kumaran, S., and Uthayakumar, M.: Performance Evaluation of Abrasive Water Jet Machining on Banana Fiber Reinforced Polyester Composite, J. Nat. Fibers, Vol. 14, No. 3, pp. 450-457, 2017.

[19] Kubade, P.R., Palash Patil, Akshay Bidgar, Akshay Papti, Pranav Potdar and Kshirsagar, R.G.: Parametric Optimization of Abrasive Water Jet Machining of Inconel718 material, Int. Res. J. Eng. and Technol., Vol. 3, No. 8, pp. 1236-1241, 2016.

[20] Sidda Reddy, D., Seshu Kumar, A. and Sreenivasa Rao, M.: Parametric Optimization of Abrasive Water Jet Machining of Inconel $800 \mathrm{H}$ Using Taguchi Methodology, Universal J. Mech. Eng., Vol. 2, No.5, pp. 158-162, 2014.

[21]Edit Tóth-Laufer and Richárd Horváth.: Fuzzy Model Based Surface Roughness Prediction of Fine
Turning, FME Transactions, Vol. 45, No. 1, pp. 181-188, 2017.

[22]Lozica T. et al: The Selection of Optimal Parameters of Gerotor Pump by Application of Factorial Experimental Design, FME Transactions, Vol. 45, No. 1, pp. 159-164, 2017.

\section{ОПТИМИЗАЦИЈА ПАРАМЕТАРА ПРОЦЕСА ОБРАДЕ АБРАЗИВНИМ ВОДЕНИМ МЛАЗОМ КОД АЛФА-БЕТА МЕСИНГА ПРИМЕНОМ ТАГУЧИЈЕВЕ МЕТОДОЛОГИЈЕ}

\section{С.Марихами, М.Равихадран, Б.Сталин, Б.С.Бабу}

Легуре обојених метала имају све већу примену у индустрији због изванредних својстава као што су чврстоћа, жилавост, тврдоћа и отпорност на корозију. Месинг спада у легуре које имају широку примену у аутомобилској индустрији, ваздухопловству, медицини и електротехници. У овом експерименту коришћен је алфа-бета месинг добијен техником ливења мешањем а особине материјала су испитане скенирајућим електронским микроскопом и анализом енергетске дисперзије х-зрака. У циљу проучавања обраде алфа-бета месинга помоћу Тагучијеве методологије узети су у обзир следећи параметри процеса обраде: притисак воде, унакрсна брзина и брзина масеног протока. Утицај ових параметара на храпавост површине и брзину скидања материјала је изучаван варирањем контролних параметара процеса. Оптимална пермутација параметара је добијена за максималне вредности храпавости површине и брзине скидања материјала. Анализом варијансе су утврђени најважнији пара-метри. 